\title{
PENGATURAN KARANTINA TUMBUHAN DALAM PENGAWASAN BUAH IMPOR DI INDONESIA
}

\author{
Ni Putu Wirastha Wisnuswari, I Nyoman Putu Budiartha, Desak Gde Dwi Arini \\ Fakultas Hukum, Universitas Warmadewa, Denpasar-Bali, Indonesia \\ fararasta870@gmail.com, budiarthaputu59@gmail.com, arinidesak1966@gmail.com
}

\begin{abstract}
Abstrak
Praktik pemberian zat-zat kimia pada buah-buahan agar tetap awet dan terlihat segar masih tetap saja ditemukan. Bentuk kecurangan ini dapat terjadi dan bisa lolos masuk ke pasaran buah di Indonesia tidak adanya instansi yang khusus memperhatikan dan menjalankan karantina. Tujuan penelitian ini untuk mengungkap pengaturan karantina tumbuhan dalam ketentuan peraturan perundang-undangan serta model pengawasan terhadap buah impor yang akan dipasarkan dan dikonsumsi masyarakat. Tipe penelitian yang digunakan dalam penelitian ini adalah penelitian hukum normatif. Sumber bahan hukum yang digunakan yaitu sumber hukum primer, sekunder dan tersier. Teknik pengumpulan bahan hukum yang digunakan dalam penelitian ini yaitu teknik studi dokumen dan studi Kepustakaan. Setelah data dikumpulkan, maka selanjutnya di analisis secara deskriptif. Hasil penelitian menunjukkan bahwa pengaturan karantina tumbuhan dalam Undang-Undang Republik Indonesia Nomor 21 Tahun 2019 Tentang Karantina Hewan, Ikan dan Tumbuhan dan diatur pula dalam Peraturan Pemerintah Nomor 14 Tahun 2002 tentang Karantina Tumbuhan. Model pengawasan terhadap buah impor yang akan dipasarkan dan dikonsumsi masyarakat, dilakukan sesuai prosedur yakni setiap media pembawa (tumbuhan dan bagian-bagiannya dan/atau benda lain) dikenakan tindak karantina tumbuhan, dilakukan pemeriksaan fisik/visual dan dilanjutkan pemeriksaan kesehatan sesuai target OPTK.
\end{abstract}

Kata Kunci: Pengaturan Karantina, Pengawasan Buah Impor, Tumbuhan.

\begin{abstract}
The practice of applying chemical substances to fruits to keep them fresh and look fresh is still being discovered. This form of fraud can occur and can pass into the fruit market in Indonesia in the absence of an agency that specifically pays attention to and carries out quarantine. The purposes of this study are to reveal the plant quarantine arrangements in the provisions of the legislation on the supervision and model for imported fruit that will be marketed and consumed by the public. The type of research used in this research is normative legal research. Sources of legal materials used are primary, secondary and tertiary sources of law. The technique of collecting legal materials used in this research is the technique of document study and literature study. After the data is collected, then it is analyzed descriptively. The results of the study show that the regulation of plant quarantine is in the Law of the Republic of Indonesia Number 21 of 2019 concerning Animal, Fish and Plant Quarantine and is also regulated in Government Regulation Number 14 of 2002 concerning Plant Quarantine. The control model for imported fruit to be marketed and consumed by the public is carried out according to the procedure, namely that each carrier medium (plants and their parts and/or other objects) is subject to plant quarantine, physical/visual inspection is carried out and continued with health checks according to the OPTK target.
\end{abstract}

Keywords: Quarantine Management, Control of Imported Fruits, Plants.

\section{PENDAHULUAN}

Memasuki era globalisasi dan perdagangan bebas, persaingan hidup semakin tinggi, arus perdagangan barang dan/atau jasa semakin meluas bahkan melintasi batas-batas wilayah suatu Negara dan kebutuhan masyarakat akan informasi pun semakin tinggi (Adolf, 2009). Hal tersebut mengakibatkan masyarakat lebih mudah dalam mencari kebutuhan yang mereka perlukan. Kondisi tersebut tentunya memberikan hal yang baik pada para konsumen karena dapat menemukan dan bahkan memilih barang yang mereka inginkan dengan mengklasifikasikan jenis, harga bahkan toko yang menjualnya.

Salah satu kebutuhan pokok bagi masyarakat adalah jenis barang konsumsi rumah tangga, seperti sayur mayur, bahan makanan pokok, atau pun buah- buahan. Ketertarikan masyarakat pada buah-buahan impor juga menjadi sebab meningkatnya kebutuhan negara untuk mengimpor buah. 
Buah-buahan impor selain rasanya yang enak, bentuk buah yang besar juga dapat menarik perhatian masyarakat Indonesia (MS, 2000). Konsumsi buah-buahan yang tinggi di masyarakat disebabkan kesadaran masyarakat yang tinggi untuk kesehatan tubuh terlebih lagi dalam kondisi pandemi Covid19 saat ini, konsumsi buah-buahan dan vitamin yang sifatnya alami terus meningkat. Kondisi ini mewajibkan konsumen agar dapat jeli untuk memilih dan memilih mana buah-buahan yang akan dikonsumsi untuk rumah tangganya.

Salah satu bentuk pemenuhan atas kebutuhan buah-buahan di pasaran adalah dengan melakukan impor buah dari luar negeri. Buah impor juga banyak beredar di pasar tradisional dan pasar modern yang ada di Kota Denpasar, yang mana peminat akan buah-buah impor ini cukup banyak dibandingkan dengan buah lokal, dan buah impor juga lebih menguntungkan bagi penjual buah-buahan di pasar seperti buah impor apel dan anggur. Dengan adanya budaya masyarakat Hindu yang juga mempergunakan buah sebagai bagian dari "banten" yang dipersembahkan saat upacara juga memberikan dampak semakin banyaknya penggunaan dan konsumsi buah impor.

Namun, sejalan dengan meningkatnya konsumsi buah-buahan di masyarakat terdapat bentuk kecurangan yang dilakukan oleh pihak importir atau pun pemasok buah impor dengan menambahkan zat-zat kimia yang berbahaya. Penambahan zat tersebut dilakukan untuk membuat buah-buah tersebut lebih awet dan tidak busuk terutama selama proses pengiriman dan masuk ke Indonesia. Indonesia sendiri telah memiliki ketentuan hukum khusus dalam menangani kondisi buah-buahan impor dengan zat kimia berbahaya, yang diatur dalam Peraturan Pemerintah Republik Indonesia Nomor 14 Tahun 2002 Tentang Karantina Tumbuhan.

Namun praktik pemberian zat-zat kimia pada buah-buahan tersebut agar buah-buahan tetap awet dan terlihat segar masih tetap saja ditemukan. Penggunaan zat-zat kimia tersebut akan berdampak pada kesehatan konsumen. Beberapa kasus yang sempat terjadi di Indonesia adalah seperti buah apel mengandung bakteri Listeria Monocytogenes yang diimpor dari California, Amerika Serikat serta ada juga kasus jeruk dan apel yang mengandung residu logam berat dan ada juga yang berformalin. Bentuk kecurangan ini dapat terjadi dan bisa lolos masuk ke pasaran buah di Indonesia disebabkan tidak adanya instansi yang khusus memperhatikan dan menjalankan karantina, karena selama ini diatur dalam peraturan perundang-undangan karantina hanya dilaksanakan oleh instansi pemerintah seperti Kementerian Pertanian, Kementerian Kehutanan dan lain sebagainya. Sehingga perlunya penormaan baru dengan pembentukan lembaga khusus yang melaksanakan karantina bagi hortikultura yang diimpor masuk ke Indonesia.

Terdapat penelitian yang relevan dengan penelitian ini. Salah satunya penelitian dari (Patros \& Azilfan, 2016) yang mengungkapkan bahwa pengaruh implementasi aturan karantina pertanian di Batam telah dilaksanakan berdasarkan Perundang-undangan yang berlaku. Adapun upaya yang ditempuh oleh Balai Karantina Kelas 1 Batam dalam mengefektifkan aturan karantina dengan Proses peningkatan pelayanan publik di Balai Karantina Kelas 1 Batam adalah mengenai kesadaran petugas itu sendiri harus selalu dibina untuk meminimalisir terjadinya pelanggaran.

Berdasarkan pemaparan diatas, maka didapat suatu tujuan penelitian yaitu pengaturan karantina tumbuhan dalam ketentuan peraturan perundang-undangan serta model pengawasan terhadap buah impor yang akan dipasarkan dan dikonsumsi masyarakat.

\section{METODE PENELITIAN}

Jenis penelitian yang diaplikasikan adalah jenis penelitian hukum normatif, menurut Soerjono Soekanto, penelitian hukum normatif didasarkan kepada penelitian kepustakaan atau dengan menggunakan bahan hukum sekunder lainnya (Soekanto \& Mamudji, 1995). Adapun sumber bahan hukum yang digunakan yaitu bahan hukum primer terdiri dari perundang-undangan, catatan resmi atau risalah dalam pembuatan perundang-undangan dan putusan-putusan hakim yang telah mendapatkan keputusan hukum tetap. Bahan hukum sekunder yaitu bahan yang dikumpulkan dengan referensi buku teks, bahan hukum lainnya yang dalamnya mengandung pandangan-pandangan hukum para yuris. Penggunaan bahan hukum sekunder dalam penelitian ini mempergunakan buku dan jurnal hukum serta lain sebagainya yang berkaitan dengan isu hukum yang diteliti (Sedarmayanti \& Hidayat, 2002). Bahan hukum tersier adalah bahan hukum yang dipergunakan dengan mempelajari kamus hukum, ensiklopedia dan bahan hukum tersier lainnya. Dalam penelitian ini bahan hukum tersier yang dipergunakan yaitu Kamus Besar Bahasa Indonesia, Kamus Hukum dan media lainnya yang berkaitan dengan isu hukum yang diteliti. Teknik pengumpulan bahan hukum yang digunakan dalam penelitian 
ini yaitu teknik studi dokumen, dipergunakan untuk melakukan bentuk catatan terhadap sumber bahan hukum primer dan bahan hukum sekunder yang selanjutnya dilakukan dalam menyelesaikan permasalahan yang berkaitan dengan isu hukum yang dibahas; Studi Kepustakaan, merupakan teknik yang dipergunakan guna menemukan data mempergunakan penelaah terhadap catatan, buku yang berkaitan dan berhubungan dengan isu hukum yang akan diteliti; Studi Internet, suatu teknik yang dipergunakan dengan mengumpulkan bahan atau data yang dicari dengan pertanyaan- pertanyaan atau kata-kata yang berkaitan dengan isu hukum di internet. Metode yang digunakan dalam pengolahan bahan hukum, yaitu metode analisis dengan bahan hukum yang dideskripsikan mengacu pada masalah yang diteliti serta dikaitkan dengan doktrin-doktrin hukum yang berdasarkan ketentuan peraturan perundang-undangan. Adapun analisis deskriptif dilakukan dengan memberikan suatu gambaran yang komprehensif dan juga sistematis terhadap isu hukum yang diteliti.

\section{HASIL DAN PEMBAHASAN}

\section{Pengaturan Karantina Tumbuhan dalam Ketentuan Peraturan Perundang-undangan}

Karantina tumbuh-tumbuhan, yang digunakan di Indonesia sejak kemerdekaan sampai awal tahun 1980-an. Menurut Kamus Umum Bahasa Indonesia tanaman adalah apa saja yang ditanam: sayur, bunga, rumput semuanya termasuk tanaman keras, tanaman sela, dan tanaman bermusim. Sedangkan tumbuhan adalah semua yang tumbuh di atau dari tanah, seperti pohon-pohonan, perdu, rumputrumputan. Sedangkan tumbuh-tumbuhan adalah semua jenis tanaman apa saja yang tumbuh di atau dari tanah: pohon kayu, buah buahan, sayur-sayuran, bunga-bungaan, semak belukar, rumputrumputan (Badudu \& Zain, 2001). Pelaksanaan karantina tumbuh-tumbuhan dilakukan pada tempat pemasukan dan/atau pengeluaran yang ada di luar instalasi karantina, seperti gudang, alat angkut, pelabuhan, bandar udara, dan lain sebagainya). Dalam hal kondisi tertentu, pelaksanaan karantina tumbuh-tumbuhan dapat saja dilaksanakan pada tempat di luar tempat pemasukan dan/atau pengeluaran. Karantina tumbuhan merupakan kewajiban setiap pihak importir dengan tujuan untuk menghindari bahan yang diimpor tersebut tidak mengandung bakteri dan penyakit berbahaya yang menempel atau terkandung dalam bahan tumbuhan yang diimpor ke Indonesia. Dalam pelaksanaannya hukum yang dibuat di suatu negara memiliki tujuan yang diharapkan guna menjadikan suatu negara yang sejahtera. Tujuan hukum yaitu, mencakup kepastian hukum, kemanfaatan, dan keadilan (Atmadja, I Dewa Gede Budiartha, 2018). Dalam Pasal 2 dan 3 Peraturan Pemerintah Nomor 14 Tahun 2002 tentang Karantina Tumbuhan, mengenai setiap media pembawa yang telah dimasukkan ke dalam wilayah Indonesia maupun yang dibawa atau dikirim dari satu area ke area lain di Indonesia harus dilengkapi sertifikat kesehatan, melalui tempat pemasukan yang telah ditetapkan, dilaporkan dan diserahkan kepada petugas karantina untuk dilakukan tindakan karantina. Selain kewajiban di atas, sangat dimungkinkan adanya kewajiban tambahan yang ditetapkan oleh menteri terkait persyaratan teknis dan/atau kelengkapan dokumen terkait karantina tumbuhan.

\section{Model Pengawasan Terhadap Buah Impor yang akan dipasarkan dan dikonsumsi Masyarakat}

Impor adalah proses transportasi barang atau komoditas dari suatu negara ke negara lain secara legal, umumnya dalam proses perdagangan. Proses impor umumnya adalah tindakan memasukan barang atau komoditas dari negara lain ke dalam negeri (MS, 2004). Kegiatan impor melibatkan 2 (dua) negara yang berkepentingan, dalam hal ini diwakili oleh masing-masing perusahaan dari negara asal dengan menjalin perjanjian berkaitan dengan objek barang yang akan diimpor ke negara tujuan. Pelaksanaan impor barang dalam jumlah yang besar, harus dilakukan dengan seizin dari bea cukai masing-masing negara pengirim dan negara penerima. Pelaksanaan impor penting dilakukan untuk memenuhi kebutuhan dari negara penerima, selain impor adanya pelaksanaan ekspor yang juga dilakukan dengan maksud dan tujuan ekonomis. Terhadap model pengawasan yang dilakukan oleh Pemerintah Indonesia mengenai peredaran buah-buahan impor dilakukan sebagaimana prosedur dalam Undang-Undang Nomor 21 Tahun 2019 Tentang Karantina Hewan, Ikan dan Tumbuhan, yakni:

1) Setiap media pembawa, baik itu tumbuhan dan bagian-bagiannya yang memasuki wilayah negara Indonesia diberlakukan kegiatan karantina tumbuhan dengan metode pemeriksaan secara visual pada objek impor dan pemeriksaan fisik, serta dilanjutkan dengan pemeriksaan standar adanya penyakit atau bakteri pada objek tumbuhan impor tersebut; 
2) Setiap jenis buah yang masuk ke wilayah Negara Republik Indonesia dikenakan tindakan Karantina Tumbuhan sesuai dengan prosedur yang telah ditetapkan dalam Undang-undang dan Peraturan Pemerintah. Tindakan karantina tersebut berupa pemeriksaan, pengasingan, pengamatan, perlakuan, penahanan, penolakan, pemusnahan dan pembebasan.

Perlindungan Konsumen adalah bagian yang tak terpisahkan dari kegiatan bisnis yang sehat. Keseimbangan perlindungan hukum dalam kegiatan bisnis yang sehat antara pembeli, penjual dan pemerintah, tidak adanya perlindungan yang seimbangan menumbulkan pembeli berada pada posisi yang lemah (Astari et al., 2020). Sesungguhnya mekanisme pengawasan dan pelaksanaan masuknya buah- buahan impor ke Indonesia terlebih dahulu dilakukan proses karantina yang dalam hal ini adanya tindakan berupa pemeriksaan, pengasingan, pengamatan, perlakuan, penahanan, penolakan, pemusnahan dan pembebasan. Kemudian dalam hal pengawasan, pemeriksaan, pengasingan, pengamatan, perlakuan, penahanan, penolakan, pemusnahan dan pembebasan telah ditetapkan dan dibatasi hanya melalui 4 pintu masuk seperti yang tercantum dalam Pasal 14 Ayat (1) Peraturan Menteri Pertanian Nomor 42 Tahun 2012 Tentang Tindakan Karantina Tumbuhan Untuk Pemasukan Buah Segar Dan Sayuran Buah Segar Ke Dalam Wilayah Negara Republik Indonesia.

Prosedur karantina tumbuhan dilakukan sebagai upaya mencegah masuk dan berkembangnya hama dan penyakit karantina, yang memiliki potensi merusak kelestarian sumber daya alam hayati, ke wilayah Indonesia dan mencegah tersebarnya dari suatu area ke area lain di dalam wilayah Indonesia, serta mencegah keluarnya hama dan penyakit tertentu dari wilayah Indonesia, dilakukan tindakan karantina. Dalam tindakan karantina di atas, sanksi tindakan yang diberikan berupa penolakan dan pemusnahan terhadap jenis objek karantina yang teridentifikasi adanya penyakit dan bakteri berbahaya, dengan sanksi tersebut, sebenarnya hama dan penyakit karantina, hama organisme pengganggu tumbuhan karantina dapat dicegah penularannya.

\section{SIMPULAN DAN SARAN}

\section{Simpulan}

Pengaturan karantina tumbuhan dalam ketentuan peraturan perundang- undangan diatur pada Pasal 2 dan 3 Peraturan Pemerintah Nomor 14 Tahun 2002 tentang Karantina Tumbuhan mengenai setiap media pembawa yang telah dimasukkan ke dalam wilayah Indonesia maupun yang dibawa atau dikirim dari satu area ke area lain di Indonesia harus dilengkapi sertifikat kesehatan, melalui tempat pemasukan yang telah ditetapkan, dilaporkan dan diserahkan kepada petugas karantina untuk dilakukan tindakan karantina. Adapun model pengawasan terhadap buah impor yang akan dipasarkan dan dikonsumsi masyarakat, dilakukan sesuai prosedur dalam Undang-undang Nomor 21 Tahun 2019 yakni setiap media pembawa (tumbuhan dan bagian-bagiannya dan/atau benda lain) yang dimasukkan ke dalam wilayah Negara Republik Indonesia dikenakan tindak karantina tumbuhan, dilakukan pemeriksaan fisik/visual dan dilanjutkan pemeriksaan kesehatan sesuai target OPTK.

\section{Saran}

Kepada pemerintah dalam hal ini institusi terkait, sebaiknya meningkatkan pengawasan terhadap masuknya buah impor. Salah satu caranya adalah dengan pembentukan ketentuan hukum yang memperketat perizinan masuknya buah impor, sehingga benar-benar terseleksi buah impor yang masuk ke wilayah Indonesia adalah memang bebas dari segala jenis virus dan penyakit tanaman. Kepada masyarakat khususnya yang sering mengkonsumsi buah impor agar lebih waspada dan berhati-hati dalam memilih buah impor. Agar selalu memperhatikan anjuran pemerintah atau institusi terkait mengenai perkembangan informasi adanya pelarangan konsumsi merek buah impor tertentu di pasaran.

\section{DAFTAR PUSTAKA}

Adolf, H. (2009). Hukum Perdagangan Internasional. Raja Grafindo Persada, Jakarta.

Astari, A. A. M. A. R. L., Budiartha, I. N. P., \& Ujianti, N. M. P. (2020). Pengawasan terhadap Transaksi Bisnis E-Commerce dalam Mewujudkan Perlindungan Konsumen. Jurnal Konstruksi Hukum, 1(1), 38-43.

Atmadja, I Dewa Gede Budiartha, I. N. P. (2018). Teori-teori Hukum. Setara Press, Malang. Badudu, J. ., \& Zain, S. M. (2001). Kamus Umum Bahasa Indonesia. Pustaka Sinar Harapan. MS, A. (2000). Seluk Beluk dan Teknik Perdagangan Luar Negeri. Lembaga Manajemen PPM dan 


\section{Penerbit PPM, Jakarta.}

MS, A. (2004). Strategi Memasuki Pasar Ekspor. Lembaga Manajemen PPM, Jakarta.

Patros, A., \& Azilfan, Y. (2016). Pengaruh Implementasi Aturan Karantina terhadap Perdagangan Produk Pertanian Antar Negara di Batam. Journal of Law and Policy Transformation, 1(1), 5671.

Sedarmayanti, \& Hidayat, S. (2002). Metodologi Penelitian. Mandar Maju, Bandung.

Soekanto, S., \& Mamudji, S. (1995). Penelitian Hukum Normatif Suatu Tinjauan Singkat. Rajawali Pers,Jakarta. 